\title{
The "Fusion" Between Direct Democracy and Representative Democracy Towards a Concept of Participatory Democracy
}

Blerina Muskaj

PhD, University "Aleksandër Moisiu" Durrës-Albania

\section{Abstract}

Democracy is an ancient institution that takes us back to ancient Greece, despite its age-old age, has been the center of many philosophical debates several times. Without any doubt this form of government, although very critical, has an extraordinary ability to survive, persist and preserve over the centuries. Perhaps because it has been able to take different forms according to the historical needs of a country. Many authors have focused on the theme of democracy, and argued for ideas other right on its potential survival in the modern, globalized world as we know prevails more representative system of democracy. Today it seems that there is a claim of direct democracy but also there is a certain difficulty of the citizen committed to a life with unbridled pace of being able to reconcile social life with the public life. With the birth of new national and supranational institutional dimensions, such as those of the European Union, there is also a need for a new model of legislative participation, and here we see the birth of a different form of democracy, a middle ground between direct and indirect democracy, that is, participatory democracy. The latter presents itself as a push from below to bring its voice to political, decision-making and legislative institutions. The goal of this analysis, is first of all investigate and reason about what is the best form of democracy, that is direct, or to representative and participatory. To get to these considerations, the argument need for a historical and philosophical journey reaching out to a legal definition. Therefore, the topic will need to be compared with the institutions that are linked to it, such as the European Citizens' Initiative. The ambition is to understand also the democratic challenge of the European institutions, this through a historical, legal and philosophical investigation, with the aim of better understanding the legal reality of an instrument as important as that of democracy, where individuals are primary.

Keywords: direct democracy, representative democracy, participatory democracy, European Citizens' Initiative. 


\section{Introduction}

As we have already stressed, democracy takes us far back in time, and on this aspect scholars are all in agreement, we see its birth in the city-state of Athens, (5th-6th century BC).

Its true etymology also grasps its true essence, in fact democracy means government or strength of the people.

Scholars believe that the classical democracy known in Athens had the characteristics of a direct form of democracy, in that the citizens could personally participate in the important decisions for the community.

These assemblies were called ecclesia, and it was the place where citizens could debate and discuss issues affecting the whole of society.

It is noted that these assemblies could only make sense in not very large societies, since bringing together all the individuals, or agreeing on a large number of individuals, became very difficult. Here the moment of the decision needed a not very high and contained number of citizens (H. Kelsen, 2010).

This is a reality that can be found even today in modern states, in truth it seems that direct democracy also works much better today in small states, such as Switzerland.

The question that naturally arises is, when does direct democracy become a representative democracy? Understanding this historical passage is very important for our analysis as the key to understanding the evolution of this governing mechanism so influential for our times.

It would seem that, the power of the State has snatched the directed democracy at the population, and instead it is not so, it was the citizens who gave up their democracy as they were taken up and occupied in other social and economic affairs.

In fact, with the economic development of the Greek city-states, and with the evergrowing form of a free market, the citizen prefers to be represented in government affairs. Here is the moment we see the birth of representative democracy.

It is believed that one of the facts that transformed the form of democracy is the abolition of slavery, so that having to do so many jobs alone for the ancient Athenian citizen, there was not much time left for political affairs. The representative model arose precisely as to help the individual in the exercise of his public and political functions.

In this case, democracy from direct becomes indirect, from participatory it becomes representative. Here the political representation is recognized by the citizen himself, the latter entrusts it with his choices and the management of his freedoms.

We also see this model of representative democracy, that is indirect, in other historical moments, and the French Revolution that adopts it, considering it a form 
capable of reflecting the demands of citizens. Democracy becomes a method, a system for returning sovereignty to the people who delegate it to their representatives. The sovereignty of the people as a principle is an important novelty in the modern order and is still a cardinal principle (J. J. Rousseau, 1970).

This concession is made precisely through the so-called social contract, and here democracy becomes a modern institution which is regularized not according to customary norms, but with important norms, such as constitutional ones and that affect the entire legal framework. Democracy thus presents itself as a superior principle, capable of affecting the rules that must be produced by the legislator, and capable of also being used by the constitutional judge.

Also, in the English legal system it is believed that the most effective model is that of representative democracy, where today it is still thought to be the only possible and functional form.

The concern of ancient scholars, who estimated that democracy was a form of government that could not have long life, this consideration did not come true. It has proven itself, not only capable of resisting the times, but also capable of influencing other forms of order, taking different shapes and appearances, adapting to the needs of modern, European and globalized society.

Democracy, even today in united Europe, is a form through which decisions can be made in such a way that the modern European citizen does not feel out of the choir.

Today in the era of globalization, democracy, one of the oldest institutions, transpires more modern than ever, it also seems that it will be able to influence the systems of the future, as through democratic systems it is possible to continue and make global decisions.

\section{The holders of democracy}

As we highlighted in the previous pages, from its etymology, democracy means government of the people, its definition makes it clear from the outset who are the owners of it.

In particular, following the universal suffrage, the debate on who are the real holders of democracy seems to have passed. On the other hand, it is noted that democracy has always been linked with the notion of citizenship, that is, the citizen of a given state, is the holder of the democracy which is granted to it by the provisions of the Fundamental Charter. In this perspective, the foreigner, excluded from many participation rights, such as the right to vote, cannot be subject to that particular democracy (C. Chmitt, 1982).

Today, with the phenomenon of economic globalization and with the union of the old continent, this theory seems outdated or at least needs to be revised, re-examined and reviewed in a different light. Since citizenship is European and why not, also global. 
Cosmopolitan citizenship has often been criticized by scholars, such as Sartori who believed that democracy must be defended from contamination of multiculturalism, that is, a pure democracy (G. Sartori, 2001).

Contrary to this doctrinal vein, we find Ferraioli, the latter highlights how democracy is the means for integration and must serve to defend multiculturalism (L. Ferraioli, 1994).

Instead, democracy must belong to all those who are subject to its rules, that is, to the democratic rules laid down in the various fundamental charters (F. J. Bastidia Freijedo, 1998).

\section{Direct democracy and indirect democracy, essential traits.}

A minimal definition outlines democracy as, "Those regimes characterized by the real guarantee of political participation of the adult male and female population, and of the possibility of dissent, opposition and even political competition" (M. Cotta, D. della Porta, 2001).

It is noted that democracy as an instrument of government is a multidisciplinary topic. Since it was born it has evolved together with the life of the company.

Thus, we can seize a participatory form of democracy, that is, the need for direct citizen involvement in decision making. In this case the representation of the formally elected is no longer a required form.

It is the legal rules that dictate the moment and the tools when a citizen can use his person as a means of social decisions. But despite this, there may also be voluntary means of democratic participation, that is, instruments not provided for by legal norms. Because voluntariness is an important element of the direct form of democracy.

But that we can talk about democracy we need four essential elements. The first is undoubtedly universal suffrage, that is, both men and women must vote. The second element is free elections, while the third is political pluralism which in turn makes the elections competitive. Instead the last element is the source of information. Last but most important element because without it the vote can be conditioned by the tyranny of disinformation (M. Cotta, D. della Porta, 2001).

Citizen decisions through this form are a significant contribution to making decisions that impact the whole community. This is why the state must create the conditions so that all members of a certain political ideology can access the decision-making process.

On this occasion we must underline how the jurist plays a very important role as he must always update himself on social reality, on economic and political phenomena (F. Viola, 1994). 
Le decisioni dei cittadini tramite questa forma sono un contributo significativo affinché sono delle decisioni che hanno un impatto in tutta la comunità. Ecco perché' deve essere lo Stato a creare le condizioni in modo che tutti i membri di una certa ideologia politica possono accedere al processo decisionale.

But is participation a reality, or just a utopia?

If you want to give a realistic answer to this question, you must first understand what the level of trust of the representatives is, how much they conquer their decisions and what are the boundaries of such representation and participation. In this case, democracy takes on different levels in each country. Here is another side of democracy, that of multilevels, and that there are different levels of democracy in different countries, disparate, different and unequal levels. (E. Dagnino, Paris, 2007).

Representative democracy, today is the most used form, the representative represents the interests of the nation, but in particular it represents the particular interests of citizens.

Bobbio points out that, "the only way of understanding when we speak of democracy, as opposed to all forms of autocratic government, is to consider it characterized by a set of rules, primary or fundamental, which establish who is authorized to take the collective decisions and with what procedures. " (Bobbio, 2005).

Also, it is noted that the birth of political parties played a very important role in the representative form, since the representative is above all a specialized official who in the name of the citizens questioned debates on important legislative and political issues. Here the political party takes this responsibility and becomes a means of representation, and a plural means of social communication. Hence the reason why pluralism is an important principle of fundamental charters and liberal states.

The principle of political pluralism is necessary for the institution of democracy. Consequently, even the deprivation of the representative's activity is only negated by the failure of the voters to send a mandate. Here the vote takes an important meaning as through it someone assumes our clothes, and asks for our rights, so that our freedoms are respected and guaranteed through the production of the laws.

For many philosophers, as also for Rousseau, direct democracy cannot exist, because it is impossible that most of the people are always willing to take care of political issues, gathering in assembly and always discussing the res publica.

Direct democracy indicates that public affairs must be administered by all citizens or most of them because in reality democracy does not need unanimity, but only and only the majority. Therefore the minority is not excluded from the decision-making part as it plays an important role in the democratic system, but the thought of the minority is not taken into consideration in the democratic system. In reality, no system cannot take the minority into consideration. The latter always remains 
underappreciated or unrepresented when it comes to indirect democracy. Thus the res publica is in the hands of the majority of the sovereign people.

Bobbio points out that, in order to exist direct democracy but "in the proper sense of the word, that is, in the sense in which direct means that the individual participates in the deliberation that concerns him, it is necessary that between the deliberating individuals and the deliberation that it concerns no intermediary "(N. Bobbio, 1984).

This lack of an intermediary poses modern societies, moreover states with a certain number of citizens, facing a huge problem in being able to give life directly to the democratic system. Well, it is impossible for democratic doctrine to take place without unions, parties or other intermediate bodies, at least in the "big states". This is also the reason why many scholars believe that direct democracy can only be real in small states, that is, with a small number of citizens. Only in this case are individuals the protagonists of the democratic system.

Rousseau also believed that, in order to be pure, direct democracy must "housing" outside political structures and democracy must be based on the social contract, that is, in the undamental Charters (J. J. Rousseau, 1995).

It is relevant to note that the right to vote is an obligation in this system, because if citizens do not approach the polls and boycott the democratic system this implies the non-functionality and failure of the system itself. Here participation in public life becomes a necessity, a requirement of democracy, and voting a civil obligation. It turns out that democracy, even when it is representative, needs politically active and non-passive citizens.

On the other side, it must be highlighted that, not only in Europe but throughout the world, popular consensus is an important moment for those who govern. Consent gives strength and stability, however dissent can lead to disorder and weakness of the state (J. J. Rousseau, 2012).

What most sums up the direct form of governing is that it, "differentiates the relative institutions from the elections as the main way of choosing the representatives", is that which allows the people in comparison between the system of direct democracy and the representative one, it is central in the discussion, bearing in mind that in the second type, decisions are made "by organs composed of elected representatives" (G. Morbidelli, 1997).

It also states "the term direct democracy describes a new relationship between citizens and their representatives, an evolution of the democratic system rather than its overcoming. The current democracy operates on the principle of delegation, not of direct participation: with the vote the voters' relationship with the candidates and with the choices that they will implement" (G. Casaleggio, 2014) 


\section{Participatory democracy}

Article 21 of the Universal Declaration of Human Rights states that "Everyone has the right to participate in the government of his country, both directly and through freely chosen representatives". This article highlights a link between the two forms of direct democracy and participatory democracy. The goal of our analysis will be precisely to understand which of these two forms of democracy best meets the needs of modern politics and the needs of a modern society, in the light of a united and tight-knit Europe around its European citizens.

As we have mentioned several times, indirect democracy requires sovereign power to be delegated by means of specific rules, predicted in the fundamental charters, where the people are expected to elect their deputies, i.e. representatives, through the vote. Instead, as regards the existence of direct democracy, it seems increasingly difficult to find a mechanism to bring it to life, even more difficult to divine this process when multiple states come together around a supranational organization such as that of the European Union.

What means, and what tools can be given to citizens to realize democracy directly?

The question seems to have a "digital" answer, as through these means it is possible to find a way to exercise this institution directly.

The last few years have seen a "return to fashion" of the direct form of democracy, both at the level of the European Union and internally in the countries, where the citizens themselves seem more careful to express their opinions and want to be part of the decision-making that they concern them, such as through referendums or through legislative initiatives.

An intermediate, hybrid form between direct and indirect democracy can be a solution, where in a sort of complementarity they balance and complement each other.

Another tool, modern and much discussed in recent years, is the institution of democratic partnership or better known as participatory democracy. This littleknown tool seems to be able to respond well to the need of European citizens to participate in important choices.

In particular, it better known as the European Citizens Initiative, this procedure has existed for eight years and through it one million euro-citizens, from at least a quarter of the Member States of the European Union, can invite the European Commission to present a draft law in one of the areas of its competence. These sectors in particular are: agriculture and rural development; banking and financial services; borders and security; budget, business and industry; climate action; competition; consumers; culture and media; customs, digital economy and society; economy and finance and the euro; education and training; emplyment and social affairs; energy; environment; EU enlargement; European neighbourhood policy; food safety; foreign affairs and 
security policy; fraud prevention; home affairs; humanitarian aid and civil preotection; institutional affairs; international cooperation and development; justice and fundamental rights; maritime affairs and fisheries; migration and asylum; public health; regional policy; research and innovation; single market; sport; statistics; taxation; trade; transport.

As can be seen, the sectors of the so-called "citizens' initiative" are limited, but they are not few, they are enough to embrace almost the entire life of citizens.

It should be noted that before launching an initiative, an organizational committee must be formed, which must be composed of at least seven citizens, the latter must be resident in at least seven Member States of the European Union. Another important requirement is that the initiative must come from a minimum of 1 million citizens. If the initiative meets all the conditions here, the Commission can take it into consideration. A meeting between EU officials and the organizing committee is expected within three months of the popular initiative. The latter also has the opportunity to illustrate the initiative during a public hearing in the European Parliament. This is an opportunity through which the citizen's voice can reach supranational institutions.

Furthermore, it is expected that the Commission will give a formal positive or negative response where it should also explain the reason for the presentation or nonpresentation of the law proposed by citizens.

Despite this, the European Citizens Initiative has never borne regulatory fruit, so this modern participatory initiative seems to be more pressure on the European legislator, as a rule that obliges the Commission to legislate on the proposed opinions of European citizens is not seen. Without a doubt, this appears to be a deficit of levels of democracy that exists in the European Union.

\section{Conclusion}

So classical democracy is based on the idea that citizen participation is not a conditio sine qua non, that is, it is not a condition without which it cannot occur. Participation takes on a secondary role because the citizen is engaged in private affairs. The representation was born as the voice of citizens who do not find the material time to be present in the form of direct democracy, also as a specialized representation, that is, a qualified vox populi.

Democracy therefore presents itself in multiple forms, where all its different nuances lead to a single objective, that of governing with, or in the name of, the sovereign people. Thus, the democratic principle and the principle of the sovereignty of the people are sides of the same coin.

Over the years, it seems that people feel the need to claim this sovereignty, and to be present again in making important decisions. Even more so when the European Union seems to be in crisis and solidarity is lacking. The participatory model of democracy 
best responds to these new European needs and beyond, in that it presents itself as a form of collaboration between power and the people and not as a delegation by the people to be represented. The latter model, that is, representative democracy, is not to be excluded, since participation also needs representation. That is, the representative model is a middle ground between the direct and indirect democratic model, that is, between direct democracy and representative democracy, in a sort of collaboration between public subjects and civil society.

We note that participatory democracy has an important impact in political life but also in institutional life, since it allows the citizen to be present and takes the initiative from the formation of laws, to planning, programming, up to the final moment, that is, the evaluation of results.

In this way participatory democracy translates into juridical norms capable and efficient to give life to the same participation (U. Alledretti, 2010).Through these rules, the citizen has the opportunity to decide firsthand on important issues affecting civil society.

It is always pointed out that participation requires a certain number of citizens and that decisions are always made according to the standard formula of democracy, that is, according to the rule of the majority and where unanimity can only be required in certain delicate situations.

Another characteristic is that the impulse to participate in democratic life must always come from below, that is, from the citizen himself, that's why 'both national and European institutions must give voice and means through which the people can participate in a democratic process that we can define as sharing. This can be achieved through a process of consolidation of the political awareness of national and European citizens, of increasing the democratic regularization of institutions and, finally, of combating abuses to ensure that the democratic process of participation is not corrupted.

\section{Bibliography}

[1] AA.VV., La filosofia politica di Roussea, by G. CHIODI, R. GATTI, Franco Angeli, Milan, 2012.

[2] ALLEGRETTI U., (by) Democrazia partecipativa, Firenze, 2010.

[3] BASTIDIA FREIJEDO F. J., La soberanía borrosa: la demo- cracia, Published in En Fundamentos: Cuadernos monográficos de Teoría del Estado, Derecho público e Historia constitucional, no. 1, 1998.

[4] BOBBIO N., Il Futuro della Democrazia, Einaudi, 1984.

[5] BOBBIO N., Il Futuro della Democrazia, Einaudi, 2005

[6] CASALEGGIO G., Web ergo sum, Sperling \& Kupfer, Milan, 2004.

[7] CHMITT C., Teoría de la Constitución, Alianza, Madrid, 1982.

[8] COTTA M., DELLA PORTA D., MORINO L., Scienza politica, il Mulino, Bologna, 2001. 
[9] DAGNino E., Participation, Citizenship and Democracy. Perverse Confluence and Displacement of Meanings, in C. NEVEU (by), Cultures et pratiques participatives, L'Harmattan, Paris, 2007.

[10] FERRAIOLI L., Dai Diriti del cittadino ai diritti della persona, in Various authors, La cittadinanza. Apparteneza, identità, diritti, Laterza, Rome-Bari, 1994.

[11] KELSEN H., La democrazia, 1929, Il Mulino, Bologna, 2010.

[12] MORBIDELLI G., PEGORARO L., REPOSO A., VOLPI M., Il Diritto Costituzionale Italiano e comparato, II edition, Bologna, 1997.

[13] ROUSSEAU J.-J., Il contratto sociale o Principi di diritto politico (1762), in J.J.ROUSSEAU, Scritti politici , Turin, Utet, 1970.

[14] ROUSSEAU J.-J., Lettera sugli Spettacoli, translation in Itialian, Aesthetica, Palermo, 1995.

[15] Sartori, $\quad$ G., $\quad$ La sociedad multiétnica. Pluralismo,multiculturalismoyextranjeros,Taurus, Madrid, 2001.

[16] VIOLA F., Nuovi percorsi dell'identità del giurista, in B. MONTANARI (a cura di), Filosofia del diritto: identità scientifica e didattica, oggi, Atti del Seminario di Studio - Catania, 8-10 maggio 1992, Giuffrè, Milan, 1994. 